\title{
Hubungan merokok dengan saturasi oksigen pada pegawai di fakultas kedokteran universitas Sam Ratulangi Manado
}

\author{
${ }^{1}$ Nindirah Septia \\ ${ }^{2}$ Herlina Wungouw \\ ${ }^{2}$ Vanda Doda
}

\author{
${ }^{1}$ Kandidat Skripsi Fakultas Kedokteran Universitas Sam Ratulangi Manado \\ ${ }^{2}$ Bagian Fisiologi Fakultas Kedokteran Universitas Sam Ratulangi Manado \\ Email: nindirahseptia@gmail.com
}

\begin{abstract}
Smoking is an overt behavior in which smokers inhale tobacco rolls. The degree of smoking can be determined based on the Brinkman index. Global Adults Tobacco Survey (GATS) estimates there are currently 7.9 billion adults who are actively smoking and 3.5 billion people are exposed to secondhand smoke in the workplace. This research aims to identify oxygen saturation of smokers and the correlation between smoking and oxygen saturation of administration staffs in the Medical Faculty of Sam Ratulangi University Manado. This research was a cross sectional study that was conducted on 30 administration staffs at the Faculty of Medicine, University of Sam Ratulangi. The correlation analysis was carried out using Kruskall-Wallis. Most respondents were mild smokers (63.33\%) with the average oxygen saturation 98.37. Moderate Smokers have an average oxygen saturation of 97.86, and heavy smokers 96.25. All respondents had an average oxygen saturation of 97.97. All respondents are still categorized as having normal oxygen saturation (95-100\%). Conclusion: There is a significant correlation between smoking and oxygen saturation. The more severe the degree of smoking, the lower level of oxygen saturation obtained in the blood.
\end{abstract}

Keywords: smoking, oxygen saturation, administration staff.

\begin{abstract}
Abstrak: Merokok merupakan overt behavior dimana perokok menghisap gulungan tembakau. Derajat merokok dapat ditentukan berdasarkan Index Brinkman. Global Adults Tobacco Survey (GATS) memperkirakan terdapat 7,9 milyar orang dewasa saat ini perokok aktif dan 3,5 milyar orang terpapar asap rokok di tempat kerja. Penelitian ini bertujuan untuk mengetahui saturasi oksigen pada perokok dan hubungan merokok dengan saturasi oksigen pada pegawai di Fakultas Kedokteran Universitas Sam Ratulangi Manado. Penelitian ini bersifat observasional analitik dengan rancangan penelitian potong lintang yang dilakukan pada 30 pegawai di Fakultas Kedokteran Universitas Sam Ratulangi Manado dengan uji statistik Kruskal-Wallis. Penelitian ini memiliki nilai $\mathrm{p}<0,05$. Responden terbanyak adalah perokok derajat ringan $(63,33 \%)$ dengan saturasi oksigen rata-rata 98,37. Perokok derajat sedang memiliki saturasi oksigen rata-rata 97,86 sedangkan perokok derajat berat 96,25. Seluruh responden memiliki saturasi oksigen rata-rata 97,97. Seluruh responden masih termasuk kategori saturasi oksigen baik (95-100\%). Simpulan: Terdapat hubungan yang signifikan antara merokok dengan saturasi oksigen. Semakin berat derajat merokok maka semakin rendah kadar saturasi oksigen dalam darah.
\end{abstract}

Kata kunci: merokok, saturasi oksigen, pegawai.

Merokok merupakan overt behavior tembakau. Definisi menurut Kamus Besar dimana perokok menghisap gulungan Bahasa Indonesia (KBBI) bahwa merokok 
adalah menghisap gulungan tembakau yang dibungkus dengan kertas. Definisi perokok menurut WHO untuk sekarang adalah mereka yang merokok setiap hari untuk jangka waktu minimal 6 bulan selama hidupnya. Derajat merokok dapat ditentukan berdasarkan indeks Brinkman yaitu lamanya merokok dalam tahun dikali dengan jumlah batang rokok yang dihisap perhari. Klasifikasi merokok berdasarkan indeks Brinkman dibagi menjadi tiga kategori yaitu ringan, sedang, berat. Perokok derajat ringan dengan Indeks Brinkman 0-199, perokok derajat sedang dengan Indeks Brinkman 200-599, dan perokok derajat berat dengan Index Brinkman $\geq 600 .^{1-4}$

\section{Global Adults Tobacco Survey} (GATS) memperkirakan terdapat 7,9 milyar orang dewasa saat ini perokok aktif dan 3,5 milyar orang terpapar asap rokok di tempat kerja. Indonesia menempati urutan ke-4 dunia dengan jumlah perokok $(4 \%)$ setelah China (38\%), Rusia (7\%) dan Amerika Serikat (5\%). Menurut survei Riskesdas 2013, konsumsi rokok di Indonesia cenderung meningkat pada 2013 menjadi $36,3 \%$ yang awalnya hanya $34,7 \%$ ditahun 2010. ${ }^{5}$ Angka kejadian merokok di tempat kerja semakin meningkat. Proporsi pegawai yang merokok secara aktif adalah $33,6 \%$ menduduki urutan ketiga perokok terbanyak setelah pengangguran dan wiraswasta. Setiap batang rokok mengandung beberapa jenis zat kimia, diantaranya karbon monoksida (CO), karbon dioksida (CO2), hidrogen sianida, amoniak, nitrogen oksida, senyawa hidrokarbon, tar, nikotin, benzopiren, fenol, dan kadmium. ${ }^{6}$ Hidrogen sianida yang terdapat pada rokok juga dapat menyebabkan hipoksia seluler dengan mengganggu rantai transport elektron sehingga sel tidak dapat lagi memproduksi ATP (secara aerobik) untuk aktifitas sel. ${ }^{7}$ Nitrogen oksida yang terdapat pada asap rokok dapat berubah menjadi senyawa nitrit sehingga menimbulkan akumulasi methemoglobin di dalam tubuh, akumulasi methemoglobin akan menimbulkan kurva disosiasi oksigen hemoglobin bergeser ke kiri dan oksigen tidak tersalurkan dengan baik ke jaringan sehingga dapat menyebabkan hipoksia. ${ }^{8}$

Balcerzaket dkk menyatakan bahwa pada perokok lebih dari satu bungkus rokok per hari memiliki sel darah merah lebih besar bila dibandingkan dengan yang bukan perokok. Peningkatan massa sel darah merah dijelaskan sebagai respon terhadap jaringan yang kekurangan suplai oksigen akibat dari paparan karbon monoksida (CO) dan dapat mengurangi afinitas oksigen terhadap hemoglobin sehingga dapat mempengaruhi kadar saturasi oksigen dalam darah. ${ }^{9}$ Saturasi oksigen adalah jumlah oksigen yang diangkut oleh hemoglobin, ditulis sebagai persentasi total oksigen yang terikat pada hemoglobin. Nilai normal saturasi oksigen yang diukur menggunakan oksimetri nadi berkisar antara $95-100 \%{ }^{1}$

\section{METODE PENELITIAN}

Desain penelitian yang digunakan adalah penelitian deskriptif observasional dengan pendekatan cross sectional. Penelitian dilakukan pada 10 September 2016 di Fakultas Kedokteran Universitas Sam ratulangi Manado. Populasi penelitian ini adalah seluruh pegawai di Manado. Sampel penelitian ini adalah pegawai di Fakultas kedokteran Universitas Sam ratulangi Manado. Variabel penelitian independent adalah derajat merokok ringan, sedang, berat dalam bentuk ordinal, sedangkan variabel dependen adalah saturasi oksigen dalam bentuk nominal. Penelitian tahap awal dilakukan dengan menggunakan kuesioner untuk mendata karakteristik responded, lamanya merokok dan banyaknya batang rokok yang dihisap perhari, kemudian saturasi oksigen responden diukur menggunakan pulse oxymetri. Data hasil penelitian diolah menggunakan uji statistik Kruskal-Wallis.

\section{HASIL PENELITIAN}

Penelitian dilaksanakan di Fakultas kedokteran universitas Sam Ratulangi Manado dengan total responden 30 yang memenuhi kriteria inklusi dan eksklusi. 
Usia terbanyak ialah usia $31-40$ $(30 \%)$ tahun dan usia 51-60 (30\%) sedangkan jenis kelamin terbanyak adalah laki-laki (80\%).

Tabel 1. Karakteristik dasar responden

\begin{tabular}{clc}
\hline Parameter & n & \% \\
\hline Usia & & \\
$21-30$ & 4 & 13,33 \\
$31-40$ & 9 & 30 \\
$41-50$ & 8 & 26,67 \\
$51-60$ & 9 & 30 \\
\hline Jenis kelamin & & \\
Laki-laki & 24 & 80 \\
Perempuan & 6 & 20 \\
\hline
\end{tabular}

Pada Tabel 2 didapatkan responden terbanyak adalah responden dengan lamanya merokok adalah yang merokok selama 11-20 tahun (50\%), sedangkan responden terbanyak yang mengkonsumsi jumlah rokok per hari adalah responden yang merokok 1-10 batang rokok perhari $(76,67 \%)$.

Tabel 2. Karakteristik Penggunaan Rokok oleh Responden

\begin{tabular}{ccc}
\hline \multicolumn{1}{c}{ Parameter } & n & \% \\
\hline $\begin{array}{c}\text { Lamanya merokok } \\
\text { (tahun) }\end{array}$ & & \\
$1-10$ & 6 & 20 \\
$11-20$ & 15 & 50 \\
$21-30$ & 5 & 16,67 \\
$31-40$ & 4 & 13,33 \\
\hline Jumlah Rokok (hari) & & \\
$1-10$ & 23 & 76,67 \\
$11-20$ & 25 & 16,67 \\
$21-30$ & 2 & 6,66 \\
\hline
\end{tabular}

Tabel 3 menunjukkan responden terbanyak adalah perokok derajat ringan $(63,34 \%)$ dengan saturasi oksigen rata-rata 98,37. Perokok derajat ringan, sedang dan berat memiliki saturasi oksigen rata-rata 97,97. Seluruh responden masih termasuk kategori saturasi oksigen baik (100\%).

Dari Tabel 4 dapat diketahui nilai sig ( $\mathrm{p}<0,05)$ artinya terdapat hubungan yang sangat signifikan antara merokok (ringan, sedang, berat) dengan saturasi oksigen $\left(\mathrm{SpO}_{2}\right)$.
Tabel 3. Distribusi Saturasi Oksigen Berdasarkan Derajat Merokok

\begin{tabular}{ccccc}
\hline $\begin{array}{c}\text { Index } \\
\text { Brinkman }\end{array}$ & $\%$ & $\mathbf{S p O}_{2}$ & $\begin{array}{c}\text { Mean } \\
\mathbf{S p O}_{2}\end{array}$ & $\begin{array}{c}\text { Norm } \\
\text { al }\end{array}$ \\
\hline Ringan & 63,34 & $98-100$ & 98,37 & 19 \\
Sedang & 23,33 & $97-98$ & 97,86 & 7 \\
Berat & 13,33 & $95-97$ & 96,25 & 4 \\
Total & 100 & & 97,97 & 30 \\
\hline
\end{tabular}

Tabel 4. Uji Kruskal-Wallis

\begin{tabular}{ll}
\hline Chi-Square & $\mathbf{1 6 . 0 7 6}$ \\
Df & 2 \\
Asymp. Sig. & .000 \\
\hline
\end{tabular}

\section{BAHASAN}

Hasil karakteristik responden berdasarkan usia didapatkan kelompok dengan responden terbanyak adalah kelompok usia 31-40 (30\%) dan kelompok usia 51-60 (30\%). Berdasarkan jenis kelamin, kelompok yang memiliki responden terbanyak adalah laki-laki (80\%). Berdasarkan lamanya merokok, kelompok dengan responden terbanyak yaitu kelompok yang merokok selama 1120 tahun (50\%). Distribusi responden berdasarkan jumlah konsumsi rokok perhari terbanyak yaitu responden yang merokok dengan jumlah 1-10 batang rokok perhari $(76,67 \%)$. Distribusi responden berdasarkan index Brinkman yaitu responden dengan index Brinkman ringan $(63,34 \%)$, kelompok ini adalah kelompok dengan jumlah responden terbanyak, sedangkan responden dengan index Brinkman sedang $(23,33 \%)$ dan responden dengan Index Brinkman berat $(13,33 \%)$, kelompok ini adalah kelompok dengan jumlah responden paling sedikit. Saturasi oksigen normal berkisar 95-100\%. Responden terbanyak memiliki saturasi oksigen sekitar $98 \%$. Saturasi oksigen ratarata dari seluruh responden adalah 97,97 sementara saturasi oksigen minimal adalah 95 dan saturasi oksigen maksimal adalah 100.

Pada penelitian ini memiliki variabel independen berbasis peringkat atau ordinal yang lebih dari satu yaitu merokok derajat 
ringan, sedang, berat, sedangkan variabel dependennya berskala data numerik interval yaitu saturasi oksigen dalam angka sehingga pada penelitian ini menggunakan uji anova. Uji normalitas data pada penelitian ini hasilnya adalah distribusi data tidak normal $(\mathrm{p}<0,05)$ sehingga data pada penelitian ini termasuk kategori data nonparametrik sehingga penelitian ini menggunakan uji Kruskal-Wallis (anova nonparametrik). ${ }^{10}$

Saturasi oksigen pada penelitian ini menggunakan saturasi oksigen perifer yang diukur menggunakan oksimetri nadi. Responden dengan derajat merokok ringan memiliki saturasi oksigen berkisar 98$100 \%$, responden dengan derajat merokok sedang memiliki saturasi oksigen 97-98\% sedangkan responden dengan derajat merokok berat memiliki saturasi oksigen 95-97\%. Pada penelitian ini responden terbanyak adalah perokok derajat ringan $(63,33 \%)$ dengan saturasi oksigen rata-rata 98,37. Perokok derajat ringan, sedang dan berat memiliki saturasi oksigen rata-rata 97,97. Seluruh responden masih termasuk kategori saturasi oksigen baik (100\%).

Pada penelitian ini didapatkan nilai $\mathrm{p}<$ 0,05 berarti Ho ditolak dan $\mathrm{H} 1$ diterima yang artinya merokok memiliki pengaruh yang signifikan terhadap saturasi oksigen. Pada penelitian ini, dapat diketahui bahwa semakin berat derajat merokok maka saturasi oksigen akan semakin turun. Dalam penelitian sebelumnya yang dilakukan oleh Sudaryanto terhadap 90 responden perokok hasilnya adalah $\mathrm{p}<$ 0,05 yang artinya terdapat hubungan yang signfikan antara merokok dengan saturasi oksigen, dari 90 responden terdapat 30 responden dengan saturasi oksigen dibawah normal dan 60 responden dengan saturasi oksigen normal. ${ }^{11}$

Menurut Claude Bernard pada tahun 1857 menemukan efek beracun karbon monoksida yang menyebabkan pelepasan ikatan oksigen dari hemoglobin menjadi carboxyhaemoglobin. Efek toksisitas utama dihasilkan karena hipoksia seluler yang disebabkan oleh gangguan transportasi oksigen. $\mathrm{CO}$ mengikat hemoglobin secara reversible, yang menyebabkan anemia relatif karena $\mathrm{CO}$ mengikat hemoglobin 200 kali lebih kuat daripada oksigen. Kadar $\mathrm{HbCO} 16 \%$ sudah dapat menimbulkan gejala klinis. CO yang terikat hemoglobin membuat ketersediaan oksigen untuk jaringan mengalami penurunan. ${ }^{12}$ Balcerzaket dkk menyatakan bahwa pada perokok lebih dari satu bungkus rokok per hari memiliki sel darah merah lebih besar bila dibandingkan dengan yang bukan perokok. Peningkatan massa sel darah merah dijelaskan sebagai respon terhadap jaringan yang kekurangan suplai oksigen akibat dari paparan karbon monoksida (CO) dan dapat mengurangi afinitas oksigen terhadap hemoglobin sehingga dapat mempengaruhi kadar saturasi oksigen dalam darah. ${ }^{9}$

Pada rokok juga terdapat $\mathrm{HCN}$ yang dapat menyebabkan hipoksia seluler dengan mengganggu rantai transport elektron sehingga sel tidak dapat lagi memroduksi ATP (secara aerobik) untuk aktifitas sel. ${ }^{7}$ Nitrogen oksida yang terdapat pada asap rokok juga dapat berubah menjadi senyawa nitrit sehingga menimbulkan akumulasi methemoglobin di dalam tubuh, akumulasi methemoglobin akan menimbulkan kurva disosiasi oksigen hemoglobin bergeser ke kiri dan oksigen tidak tersalurkan dengan baik ke jaringan sehingga dapat menyebabkan hipoksia. ${ }^{8}$ Teori-teori tersebut dapat dibuktikan pada penelitian ini yang diuji menggunakan uji statistik Kruskal-Wallis dengan hasil signifikansi $\mathrm{p}<0,05$ artinya terdapat perbedan antara derajat merokok ringan, derajat meroko sedang dan derajat merokok berat terhadap saturasi oksigen.

Pada penelitian ini, seluruh responden baik pada perokok derajat ringan, perokok derajat sedang maupun perokok derajat berat masih memiliki nilai saturasi oksigen yang baik (normal). Pembacaan saturasi oksigen perifer banyak di pengaruhi oleh beberapa faktor seperti hemoglobin $(\mathrm{Hb})$, sirkulasi, aktivitas dan persentase oksigen yang terhirup. Keadaan dimana $\mathrm{Hb}$ tersaturasi penuh dengan oksigen walaupun nilai $\mathrm{Hb}$ rendah maka pada pembacaan 
akan menunjukkan nilai normalnya. Oksimetri tidak akan memberikan bacaan yang akurat jika area yang dibawah sensor mengalami gangguan sirkulasi. Menggigil atau pergerakan yang berlebihan pada area sensor dapat mengganggu pembacaan $\mathrm{SpO}_{2}$ yang akurat. Semakin sedikit oksigen yang terhirup maka semakin sedikit juga oksigen yang terikat dengan hemoglobin.

Pada penelitian ini tidak memasukkan karakteristik lain yang mempengaruhi saturasi oksigen ke dalam variabel sehingga pada penelitian ini murni hanya membahas tentang pengaruh merokok derajat ringan, sedang, berat terhadap saturasi oksigen. Penelitian ini juga tidak membahas tentang jenis-jenis rokok mana yang paling bermakna terhadap penurunan saturasi oksigen. Rokok dibedakan menjadi beberapa jenis. Pembedaan ini didasarkan atas bahan pembungkus rokok, bahan baku atau isi rokok, proses pembuatan rokok, dan penggunaan filter pada rokok. ${ }^{13-5}$

\section{SIMPULAN}

Berdasarkan hasil penelitan tentang hubungan merokok dengan saturasi oksigen yang dilakukan pada pegawai di Fakultas Kedokteran Universitas Sam Ratulangi dapat disimpulkan bahwa perokok derajat sedang yang terbanyak dan seluruh pegawai yang merokok masih memiliki saturasi oksien yang normal tetapi setiap derajat merokok memiliki nilai saturasi oksigen yang berbeda. Terdapat hubungan bermakna antara derajat merokok aktif ringan, sedang, dan berat dengan kadar saturasi oksigen.

\section{SARAN}

Peneliti menyadari bahwa penelitian ini masih terdapat beberapa kekurangan sehingga peneliti menyarankan untuk mendapat hasil penelitian yang lebih baik terhadap hubungan merokok dengan saturasi oksigen maka perlu dilakukan penelitian lanjutan mengenai hubungannya dengan jenis-jenis rokok, kandungan yang terdapat dalam rokok seperti nikotin, tar dan zat lainnya sehingga dihasilkan kajian penelitian yang lebih dalam. Perlu juga diteliti faktor eksternal yang mempengaruhi saturasi oksigen pada perokok sehingga dapat menimbulkan bias pada pengukuran saturasi oksigen. Saran yang diberikan untuk responden adalah untuk berhenti merokok dan menjalani pola hidup sehat.

\section{DAFTAR PUSTAKA}

1. Schutz S. Oxygen saturation monitoring by pulse oximetry. Edisi ke-4. Amerika: AACN procedure manual for critical care; 2011.

2. U.S. Department of Health and Human Services. How Tobacco Smoke Causes Disease: What It Means to You. Atlanta: U.S. Department of Health and Human Services, Centers for Disease Control and Prevention, National Center for Chronic Disease Prevention and Health Promotion, Office on Smoking and Health, 2010 [accessed 2016 Sept 16].

3. Igari $\mathbf{K}$, Inoue $Y$, Iwai $T$. The epidemiologic and clinical findings of patients with buerger disease. Ann Vasc Surg. NCBI; 2016.

4. Peraturan pemerintah republik indonesia no 19 tahun 2003 tentang pengamanan rokok bagi kesehatan; 2016.

5. Riskesdas. Kementrian Kesehatan Republik Indonesia. Jakarta; 2013.

6. Yahya AF. Menaklukkan pembunuh No 1 . Bandung: Qanita.h.45; 2010.

7. Nelson, David L.; Cox, Michael M. Lehniger Principles of Biochemistry (3rd ed.). New York: Worth Publishers. pp. 668,670-71,676. ISBN 1-57259-153-6; 2000.

8. Hon YY, Sun H, Dejam A, Gladwin MT. Characterization of erythrocyte uptake and release and disposition pathways of nitrite, nitrate, methemoglobin, and iron-nitrosyl hemoglobin in the human circulation. Drug and metabolism and disposition USA; 2010.

9. Balcerzak $\mathbf{P} \mathbf{S}$, Lawrence Thomas, L. Arthur and Jr. Sagone. Effect of Smoking on Tissue Oxygen Supply. 20036. Blood (print ISSN 00064971, online ISSN 1528-0020), is published weekly bythe American Society of Hematology, 2021 L St, NW, Suite 900, Washington DC; 2013. 
10.Riwidikdo H. Statistik kesehatan. Mitra cendikia press: Yogyakarta; 2012.

11.Sudaryanto WT. Hubungan derajat merokok aktif ringan sedang berat dengan kadar saturasi oksigen dalam sarah $\quad(\mathrm{SpO} 2) . \quad$ Universitas Muhamadiyah Surakarta. 2015.

12.Eugene N, Bruce, Margaret C- A. 2003. Multicompanement Model Of Cartoxyhemoglobin And
Carboxymyoglobin Responses To Inhalation Of Carbon Monoxide. J Appl Physiol95; 2003

13.Sherwood L. Fisiologi manusia dari sel ke sistem. Ed ke6. Jakarta: EGC; 2011.

14.Hoffbrand AV. Moss PAH. Kapita selekta hematologi. Jakarta: EGC; 2013.

15.Marks DW. Marks AD. Smith CM. Biokimia kedokteran dasar. Jakarta: EGC; 2000. 